\title{
Two novel susceptibility loci for non-small cell lung cancer map to low-density lipoprotein receptor-related protein 5
}

\author{
YING WANG $^{1}$, YONGJUN ZHANG ${ }^{2,3}$, MEIYU FANG $^{2}$, WENGLONG BAO ${ }^{2}$ and DEHOU DENG ${ }^{2}$ \\ ${ }^{1}$ Radiotherapy Department of Gynecological Oncology; ${ }^{2}$ Department of Integration of Traditional Chinese and Western Medicine; \\ ${ }^{3}$ Zhejiang Key Laboratory of Diagnosis and Treatment Technology for Thoracic Oncology, \\ Zhejiang Cancer Hospital, Hangzhou, Zhejiang 310022, P.R. China
}

Received January 16, 2015; Accepted February 19, 2016

DOI: $10.3892 / \mathrm{ol} .2016 .4954$

\begin{abstract}
This study investigated the effect of single-nucleotide polymorphisms (SNPs) of low-density lipoprotein receptor-related protein 5 (LRP5) on the risk of developing non-small cell lung cancer (NSCLC). A total of 500 NSCLC patients and 500 healthy controls were recruited for genotyping of 11 SNPs of LRP5. The association between genotype and NSCLC risk was evaluated by computing the odds ratio (OR) and 95\% confidence interval (CI) from multivariate unconditional logistic regression analyses. Eleven Tag SNPs were detected. The frequency of the LRP5 rs3736228 T allele (18.9\% in male NSCLC cases and $23.9 \%$ in male controls) was statistically different between male NSCLCs and male controls $(\mathrm{P}=0.03)$, and the $\mathrm{T}$ allele was associated with a lower risk of NSCLC (OR=0.74; 95\% CI, 0.56-0.67), whereas the $\mathrm{C} / \mathrm{C}$ homozygous genotype and the LRP5 rs64843 T/T genotype were associated with an increased risk of NSCLC and squamous cell carcinoma ( $\mathrm{SCC})$, respectively $(\mathrm{OR}=1.43$ and 1.77, respectively). Using Haploview software, the frequency of the haplotypes of rs312009/rs3120015/rs3120014 CCC was was significantly higher in female SCC cases compared with female controls (0.064 vs. 0.009, $\mathrm{P}=0.04)$. LRP5 rs3736228 and rs64843 SNPs were significantly associated with an increased risk of NSCLC and SCC, respectively. Further studies are required to investigate the functional changes in LRP5 expression and activity in NSCLC in vitro.
\end{abstract}

\section{Introduction}

Lung cancer is the most commonly diagnosed cancer and the leading cause of cancer-related mortality worldwide. In

Correspondence to: Dr Yongjun Zhang, Department of Integration of Traditional Chinese and Western Medicine, Zhejiang Cancer Hospital, 38 Banshan Road, Hangzhou, Zhejiang 310022, P.R. China E-mail: zhangyongjun770323@163.com

Key words: non-small cell lung cancer, genetic susceptibility, low-density lipoprotein receptor-related protein 5 , single-nucleotide polymorphisms
2008, lung cancer accounted for 1.6 million of new cases and 1.4 million cancer-related mortalities worldwide (1). Non-small cell lung cancer (NSCLC) is the most common histological subtype, accounting for $\sim 85 \%$ of all lung cancers (2). NSCLC is also one of the few cancers for which there has been no substantial progress in early detection and treatment options (3). Tobacco smoke is the single most significant risk factor for lung cancer, and outdoor air pollution (4) and genetic factors are also notable factors (5-7). A previous study demonstrated that a heritable component or a gene-environment interaction leads to lung cancer development (5); for example, not all tobacco smokers suffer from lung cancer. Thus, it is crucial to identify these genes and their genetic variations to clarify their association with lung cancer risk $(6,7)$.

Low-density lipoprotein-related receptor 5 (LRP5) is a member of the family of lipoprotein receptor-related proteins (LRPs), a small group of single-pass transmembrane proteins (8). LRP5 was originally identified based on its homology to the low-density lipoprotein (LDL) receptor (9); it contains large extracellular domains, including four $\beta$-propeller motifs followed by three type 1 LDL ligand-binding domains (10), and is a transmembrane cell-surface receptor involved in receptor-mediated endocytosis of lipoprotein and protein ligands (11). Functionally, LRP5 plays a significant role in Wnt/ $\beta$-catenin signaling, and the latter is integral to developmental biology. For example, when Wnt ligands bind to a member of the Frizzled family and LRP5, it allows $\beta$-catenin to shuttle into the nucleus and bind to T-cell factor/lymphocyte-enhancing factor proteins to activate the canonical Wnt/ $\beta$-catenin signaling cascade (10). In the absence of the Wnt ligand binding to Frizzled receptors, the canonical Wnt pathway is turned off, which leads to $\beta$-catenin degradation. The non-canonical pathway may lead to proliferation of lung cancer cells (12). Signaling by the Wnt family of secreted glycolipoproteins is known to play a key role in the embryonic development of organisms ranging from nematodes to mammals, and is also implicated in several types of human cancer (13-15). In lung cancer, it has been reported that lipoprotein receptor-related protein is inactivated in more than $40 \%$ of cases (16). Another study has demonstrated that chromosome 11q is frequently altered in NSCLC (17), where LRP5 is localized. Thus, in this study, we hypothesized that LRP5 polymorphisms may play a role in susceptibility to NSCLC. 
Table I. Polymerase chain reaction primers and extensions used in the genotyping of LRP5 single-nucleotide polymorphisms.

\begin{tabular}{|c|c|c|}
\hline SNP & Primers & Sequences \\
\hline Rs4930573 & $\begin{array}{c}1 \\
2 \\
\text { Extension }\end{array}$ & $\begin{array}{l}\text { 5'-ACGTTGGATGTGTTTCCTGAACGAGCCTGC-3' } \\
\text { 5'-ACGTTGGATGTGGATGCGCCAGTGTTCCT-3' } \\
\text { 5'-CTTTCCTGCTGTGGACC-3' }\end{array}$ \\
\hline Rs312009 & $\begin{array}{c}1 \\
2 \\
\text { Extension }\end{array}$ & $\begin{array}{l}\text { 5'-ACGTTGGATGTCTTGGACTCAAGTGGATGG-3' } \\
\text { 5'-ACGTTGGATGATGTGTCCTCTATGACAGGC-3' } \\
\text { 5'-TTCCCCTTTGTTCCTGTGGC-3' }\end{array}$ \\
\hline Rs312014 & $\begin{array}{c}1 \\
2 \\
\text { Extension }\end{array}$ & $\begin{array}{l}\text { 5'ACGTTGGATGTAGGGAACGGATAGGACCAG-3 } \\
\text { 5'-ACGTTGGATGTCTGAGCTCTGTGCTGGTTG-3' } \\
\text { 5'-CCTGGAGCCCTGAGTTA-3' }\end{array}$ \\
\hline Rs3781590 & $\begin{array}{c}1 \\
2 \\
\text { Extension }\end{array}$ & $\begin{array}{l}\text { 5'-ACGTTGGATGACATGGGCCTTGCCAAAAAC-3' } \\
\text { 5'-ACGTTGGATGACGCCCTTCCCACGAAAAC-3' } \\
\text { 5'-GAGGGAGGTGTGGCCATTTCCTGCT-3' }\end{array}$ \\
\hline Rs312015 & $\begin{array}{c}1 \\
2 \\
\text { Extension }\end{array}$ & $\begin{array}{l}\text { 5'-ACGTTGGATGCTTGTGGATCACAACCAGAC-3' } \\
\text { 5'-ACGTTGGATGTGTCCTGCGAGAGGCCCTTA-3' } \\
\text { 5'-AGATGCCCTTAGAGGCCAGATCATG-3' }\end{array}$ \\
\hline Rs491347 & $\begin{array}{c}1 \\
2 \\
\text { Extension }\end{array}$ & $\begin{array}{l}\text { 5'-ACGTTGGATGGTTCTGATGATCCATGAGCC-3' } \\
\text { 5'-ACGTTGGATGCTCTTTCATCCTGTCCTGAG-3' } \\
\text { 5'-CTGATAGCCGGAGAACTTGGATGTTGC-3' }\end{array}$ \\
\hline Rs1784235 & $\begin{array}{c}1 \\
2 \\
\text { Extension }\end{array}$ & $\begin{array}{l}\text { 5'-ACGTTGGATGTAATGAACCTGTTGTGCCCC-3' } \\
\text { 5'-ACGTTGGATGCTGTTCCACAAATGATGTGC-3' } \\
\text { 5'-TTTTATGATGTGCTCACGG-3' }\end{array}$ \\
\hline Rs648438 & $\begin{array}{c}1 \\
2 \\
\text { Extension }\end{array}$ & $\begin{array}{l}\text { 5'-ACGTTGGATGTAACACTTATCGTCGTAACC-3' } \\
\text { 5'-ACGTTGGATGTGGCAGTGGTTACCAGCAAC-3' } \\
\text { 5'-ATTTTCTTAATGCCACTGAACTTCAC-3' }\end{array}$ \\
\hline Rs3736228 & $\begin{array}{c}1 \\
2 \\
\text { Extension }\end{array}$ & $\begin{array}{l}\text { 5'-ACGTTGGATGTCTTGGCAGAGCCTTGACG-3' } \\
\text { 5'-ACGTTGGATGAGACTGTCAGGACCGCTCA-3' } \\
\text { 5'-GGGAGACCGCTCAGACGAGG-3' }\end{array}$ \\
\hline Rs624947 & $\begin{array}{c}1 \\
2 \\
\text { Extension }\end{array}$ & $\begin{array}{l}\text { 5'-ACGTTGGATGTGAAAGCCAGCTGGGTGTAG-3' } \\
\text { 5'-ACGTTGGATGAACGCTGCTCCCTGTCCCTT-3' } \\
\text { 5'-ACGCACTGTCCCTTGGGGTCC-3' }\end{array}$ \\
\hline Rs607887 & $\begin{array}{c}1 \\
2 \\
\text { Extension }\end{array}$ & $\begin{array}{l}\text { 5'-ACGTTGGATGCAGGAGGGCCAGTTCTCAT-3' } \\
\text { 5'-ACGTTGGATGAAGACAAACAGAGGTCAGGC-3' } \\
\text { 5'-AAACCGGAGGGTAGGGGCCAAAT-3' }\end{array}$ \\
\hline
\end{tabular}

LRP5, low-density lipoprotein receptor-related protein 5; SNP, single-nucleotide polymorphism.

\section{Patients and methods}

Study population. A total of 500 NSCLC patients and 500 unrelated healthy controls were recruited from Zhejiang Cancer Hospital, Hangzhou, China, between March 2011 and April 2012. All cases and controls were of Chinese Han origin and lived in the same geographic region (Zhejiang province, China). Exclusion criteria included a history of previous primary cancer other than lung cancer. The controls were free of lung-related disease to avoid any probable interference from overlapping genes. The control subjects were matched to patients for gender and age. A regular smoker was defined as someone who had smoked more than one pack per year, and a current smoker or former smoker was defined as a regular smoker who still smoked in the year of the interview or in the previous year (18). This study was approved by the Ethics Committee of Zhejiang Cancer Hospital, and all of the studied subjects provided informed consent.

SNP selection and genotyping. Tagging SNPs of LRP5 were selected based on pairwise $r^{2}$ values $(\geq 0.8)$ among all common SNPs with a minor allele frequency $(\mathrm{MAF}) \geq 0.1 \mathrm{using}$ the Tagger program implemented in Haploview version 4.1 (http://www. broad.mit.edu/mpg/haploview). The Chinese HapMap database [population=Han Chinese, Beijing (CHB)] was used to select LRP5 SNPs in this study (http://www.hapmap.org).

For the genotyping of LRP5 SNPs, genomic DNA was extracted from whole blood using the AxyPrep Blood 
Genomic DNA Miniprep kit (Axygen Biosciences, Union City, CA, USA) and subjected to genotyping of LRP5 SNPs with the Sequenom MassARRAY matrix-assisted laser desorption/ionization time-of-flight mass spectrometry platform (Sequenom, San Diego, CA, USA). Primers for polymerase chain reaction (PCR) and single base extension were designed using Assay Designer software version 3.0 (Sequenom) and synthesized by Sangon Biotech (Shanghai, China; Table I).

Multiplex PCR was performed in $5 \mu \mathrm{l}$ volumes containing 0.1 units of HotStarTaq polymerase (Qiagen, Hilden, Germany), $10 \mathrm{ng}$ whole-genome-amplified genomic DNA, $2.5 \mathrm{pmol}$ of each PCR primer and $2.5 \mu \mathrm{mol}$ deoxynucleotides (dNTP; Qiagen). Thermocycling was performed at $94^{\circ} \mathrm{C}$ for $15 \mathrm{~min}$ followed by 45 cycles at $94^{\circ} \mathrm{C}$ for $20 \mathrm{sec}, 56^{\circ} \mathrm{C}$ for $30 \mathrm{sec}$, and $72^{\circ} \mathrm{C}$ for $1 \mathrm{~min}$, and a final incubation at $72^{\circ} \mathrm{C}$ for $3 \mathrm{~min}$. Unincorporated dNTPs were deactivated using 0.3 units of shrimp alkaline phosphatase (Sequenom) followed by primer extension using $5.4 \mathrm{pmol}$ of each primer extension probe, $50 \mu \mathrm{mol}$ of the appropriate ddNTP combination, and 0.5 units of iPLEX enzyme (Sequenom). The extension reactions were carried out at $94^{\circ} \mathrm{C}$ for $30 \mathrm{sec}$ and then $94^{\circ} \mathrm{C}$ for $5 \mathrm{sec}$, followed by 5 cycles at $52^{\circ} \mathrm{C}$ for $5 \mathrm{sec}$ and $80^{\circ} \mathrm{C}$ for $5 \mathrm{sec}$ for a total of 40 cycles, and then $72^{\circ} \mathrm{C}$ for $3 \mathrm{~min}$. A cation exchange resin was used to remove residual salt from the reactions. Purified primer extension reaction products were spotted onto a 384-well spectroCHIP using the MassARRAY Nanodispenser (Sequenom) and determined by the matrix-assisted laser desorption/ionization time-of-flight mass spectrometer (Sequenom). Genotype calling was performed in real time with MassARRAY RT software version 3.0.0.4 (Sequenom) and analyzed by using the MassARRAY Typer software version 3.4 (Sequenom).

Statistical analysis. All statistical calculations were performed using SPSS 13.0 for Windows (SPSS Inc., Chicago, IL, USA). Hardy-Weinberg equilibrium (HWE) testing was carried out for all SNPs using the $\chi^{2}$ test, and $\mathrm{P}<0.001$ was considered to indicate a statistically significant difference between cases and controls. The $\chi^{2}$ test was also used to assess frequencies of the selected allele and genotype between the cases and controls. The association between SNPs and NSCLC risk was evaluated by computing the odds ratio (OR) and $95 \%$ confidence interval (CI) from multivariate unconditional logistic regression analysis. Haploview software version 4.1 was used to analyze the association between haplotypes and the disease. All P-values were two-sided, and $\mathrm{P}<0.05$ was considered to indicate a statistically significant difference.

\section{Results}

Study population description and clinical characteristics. A total of 500 patients ( 350 males and 150 females) and 500 healthy controls ( 259 males and 240 females; the gender information for one control subject was not available) of Chinese Han origin were included in this study. A total of 331 patients had adenocarcinoma (ADC), while 169 had squamous cell carcinoma (SCC). There were 280 male and 21 female patients who were smokers or former smokers, and 189 male and 14 female controls who were smokers or former smokers. All patients and controls were subjected to genotyping of 11 LRP5 tag SNPs (i.e., rs4930573, rs312009, 


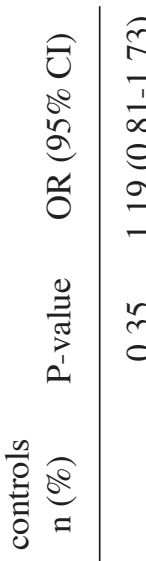

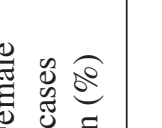
도

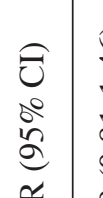

ชै

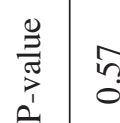

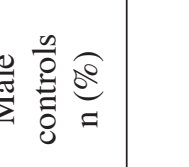

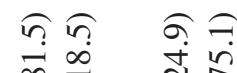

$\underset{\text { c }}{\infty} \underset{\overbrace{}}{\infty}$

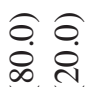

士

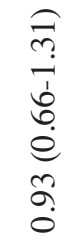

च.

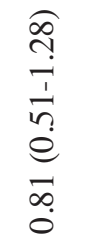

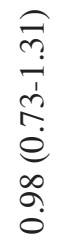

$\frac{\widehat{v}}{\stackrel{1}{*}}$

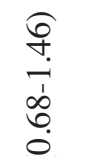

ț

รे

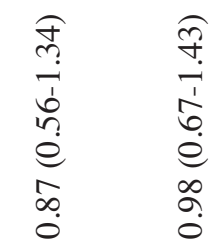

हิ $\hat{m}$ m

$\infty$

品 क

ปี

त त

(1)

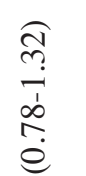

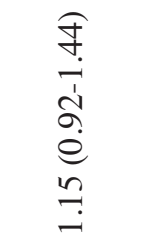

กู่

$\begin{array}{lll}0 & & \infty \\ 0 & & \infty \\ 0 & 0 \\ 0 & 0\end{array}$

$\stackrel{\infty}{\infty}$

ఠิ

กี่

ติ

oิ $\widehat{m} \hat{\circ}$

तิ

旾高

สุิ

+

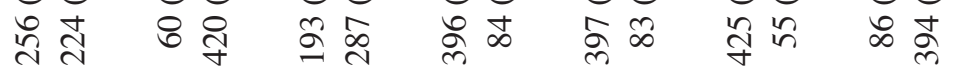

กิ

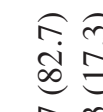

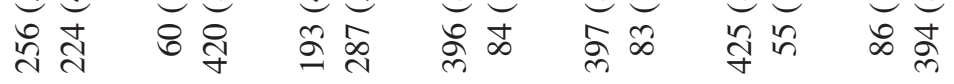

nก $\sigma=$

$\Xi \stackrel{\infty}{\infty} \equiv \infty$

Fิ $\bar{m}$

ㄷำ

ఠิ

$\approx \overparen{n}$

ळ

i.

อิ. กิ.

过年实

ले

学的

$\stackrel{\infty}{\sim}$ in

क ल

$\Xi \infty$

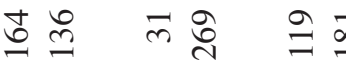

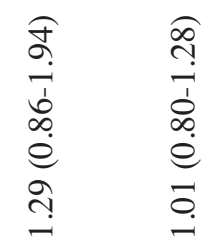

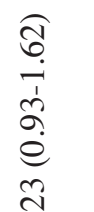

$\hat{b}$
$\overline{1}$
0
0
0
0
0

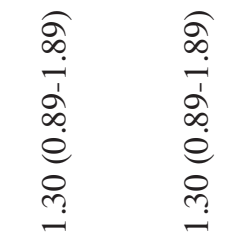

กิ

s.

$\stackrel{+}{\circ}$

$\stackrel{8}{8}$

o.

$\stackrel{\infty}{\circ} \stackrel{\infty}{\circ}$

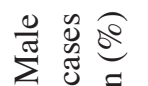

ำ $\widehat{\sigma} \widehat{\sigma}$

ลิ

สำ

ㅇํㅇ

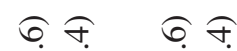

\section{(1)}


rs312014, rs3781590, rs312015, rs491347, rs1784235, rs648438, rs3736228, rs624947 and rs607887). The selection was based on the following criteria: HapMap CHB, pairwise $r^{2} \geq 0.8$, and MAF $\geq 0.1$. The cases and controls were within the HWE for these 11 Tag SNPs, and the P-values are shown in Table II.

LRP5 polymorphisms in cases and controls. The allele frequencies of LRP5 SNPs in the cases and controls were analyzed. The frequency of the rs $3736228 \mathrm{~T}$ allele was $18.9 \%$ and that of the $\mathrm{C}$ allele was $81.1 \%$ in the male NSCLC patients, whereas they were $23.9 \%$ and $76.1 \%$, respectively, for the male controls $(\mathrm{P}=0.03)$. Logistic regression analysis revealed that the $\mathrm{T}$ allele is associated with a lower risk of developing NSCLC $(\mathrm{OR}=0.74 ; 95 \% \mathrm{CI}, 0.56-0.67)$. In contrast, the frequency of rs3736228 was similar between NSCLC patients and controls and between female NSCLC patients and female controls $(\mathrm{P}>0.05)$. The differences in allele frequencies in the other 10 Tag SNPs (i.e., rs4930573, rs312009, rs312014, rs3781590, rs312015, rs491347, rs1784235, rs648438, rs624947 and rs607887) between cases and controls, male patients and male controls, as well as female patients and female controls were not statistically significant (Table III).

The genotype distribution of $L R P 5$ SNPs was also analyzed. For rs3736228 polymorphisms, logistic regression analysis revealed that the $\mathrm{C} / \mathrm{C}$ major allele homozygote was associated with an increased risk of NSCLC in the male population (C/C frequencies were $64.9 \%$ and $56.4 \%$ in male NSCLC patients and controls, respectively; $\mathrm{OR}=1.43 ; 95 \% \mathrm{CI}, 0.33-1.99 ; \mathrm{P}=0.03$; Table IV). For rs64843 polymorphisms, the T/T major allele homozygote had a 1.77-fold greater risk of developing SCC compared with the $\mathrm{C} / \mathrm{C}$ and $\mathrm{C} / \mathrm{T}$ genotypes (95\% CI, 1.02-3.04; $\mathrm{P}=0.04)$. The $\mathrm{T} / \mathrm{T}$ frequencies were $87.0 \%$ and $79.2 \%$ in male SCC patients and controls, respectively (Table V).

Haploview software identified two blocks among NSCLCs, ADCs and controls, and male NSCLCs, male ADCs and male controls: the haplotypes were CG, TC and CC in Block 1 (the length of one block was $6 \mathrm{~kb}$, including rs312009 and 3120015), and TTC, CCT and TTT in Block 2 (the length of the other block was $27 \mathrm{~kb}$, including rs491347, rs1784235 and rs607887). Two blocks were identified among female NSCLCs, female ADCs and female controls: the haplotypes were CG, TC and $\mathrm{CC}$ in Block 1 (the length of one block was $6 \mathrm{~kb}$, including rs312009 and 3120015), and TTCC, CCTT, TTTC and TTTT in Block 3 (the length of the other block was $31 \mathrm{~kb}$, including rs491347, rs1784235, rs607887 and rs3736228). Two blocks were identified among SCCs and controls, and male SCCs and male controls: the haplotypes were CGC, TCG, CCG and CGG in Block 4 (the length of one block was $7 \mathrm{~kb}$, including rs312009, rs3120014 and rs3120015), and TTC, CCT and TTT in Block 2 (the length of the other block was $27 \mathrm{~kb}$, including rs491347, rs1784235 and rs607887). Two blocks were identified among female SCCs and female controls: the haplotypes were CGC, TCG, CCG, CGG and CCC in Block 4 (the length of one block was $7 \mathrm{~kb}$, including rs312009, rs3120015 and rs3120014), and TTCC, CCTT, TTTC and TTTT in Block 3 (the length of the other block was $31 \mathrm{~kb}$, including rs491347, rs1784235, rs607887 and rs3736228). Among these results, only the frequency of haplotypes rs312009/rs3120015/rs3120014 CCC were significantly higher in female SCC patients vs. female controls (0.064 vs. $0.009 ; \mathrm{P}=0.04$; Table VI). 


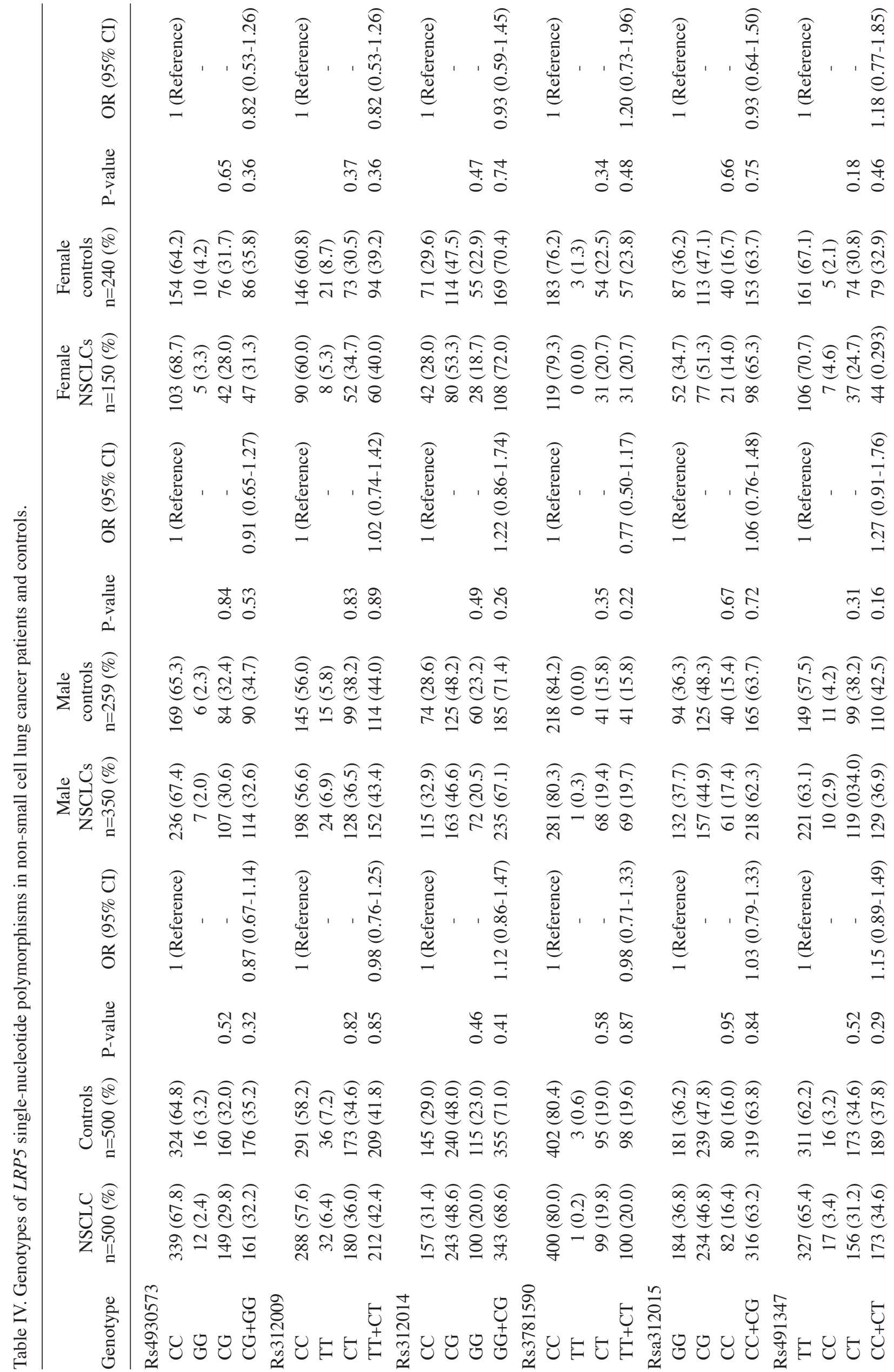




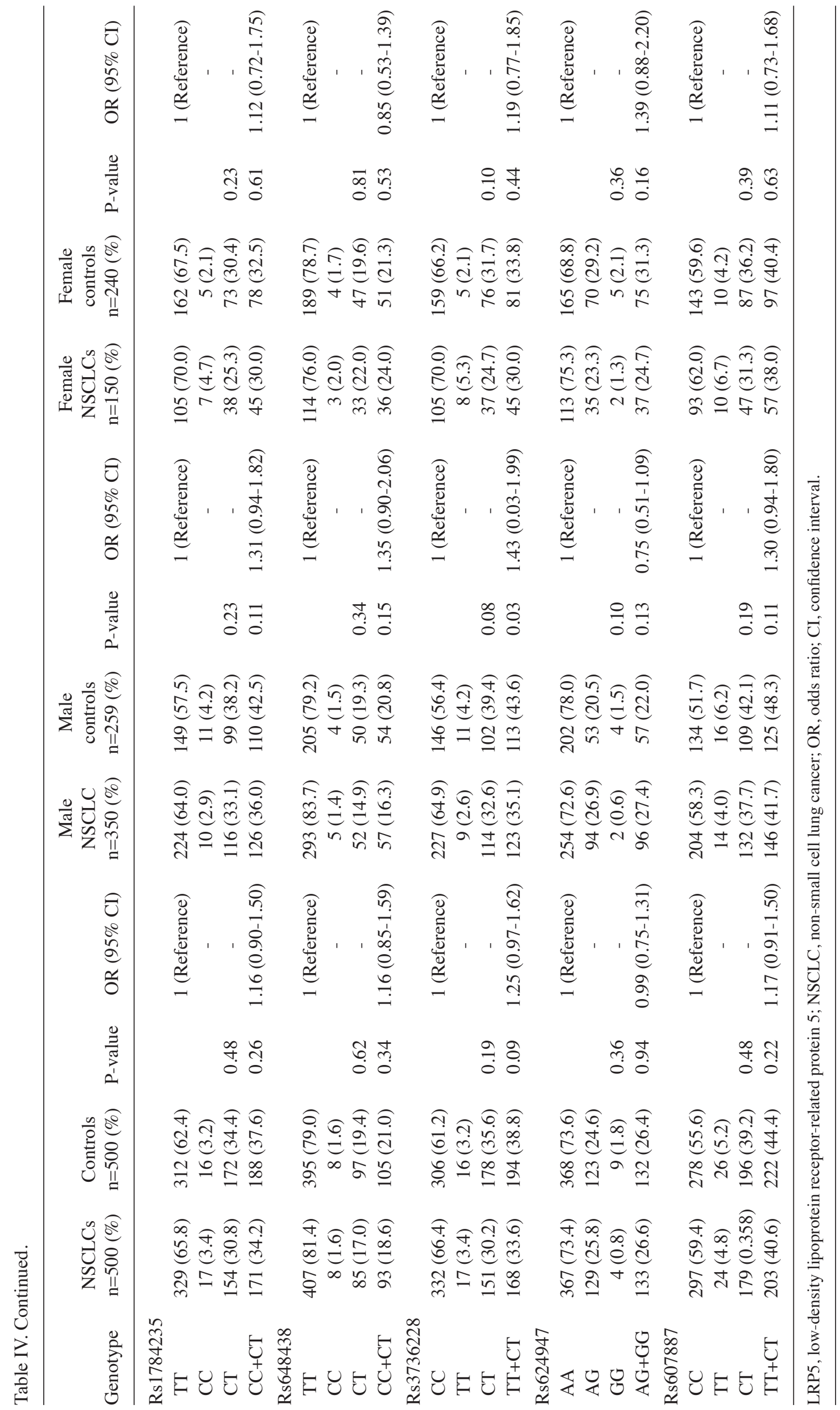




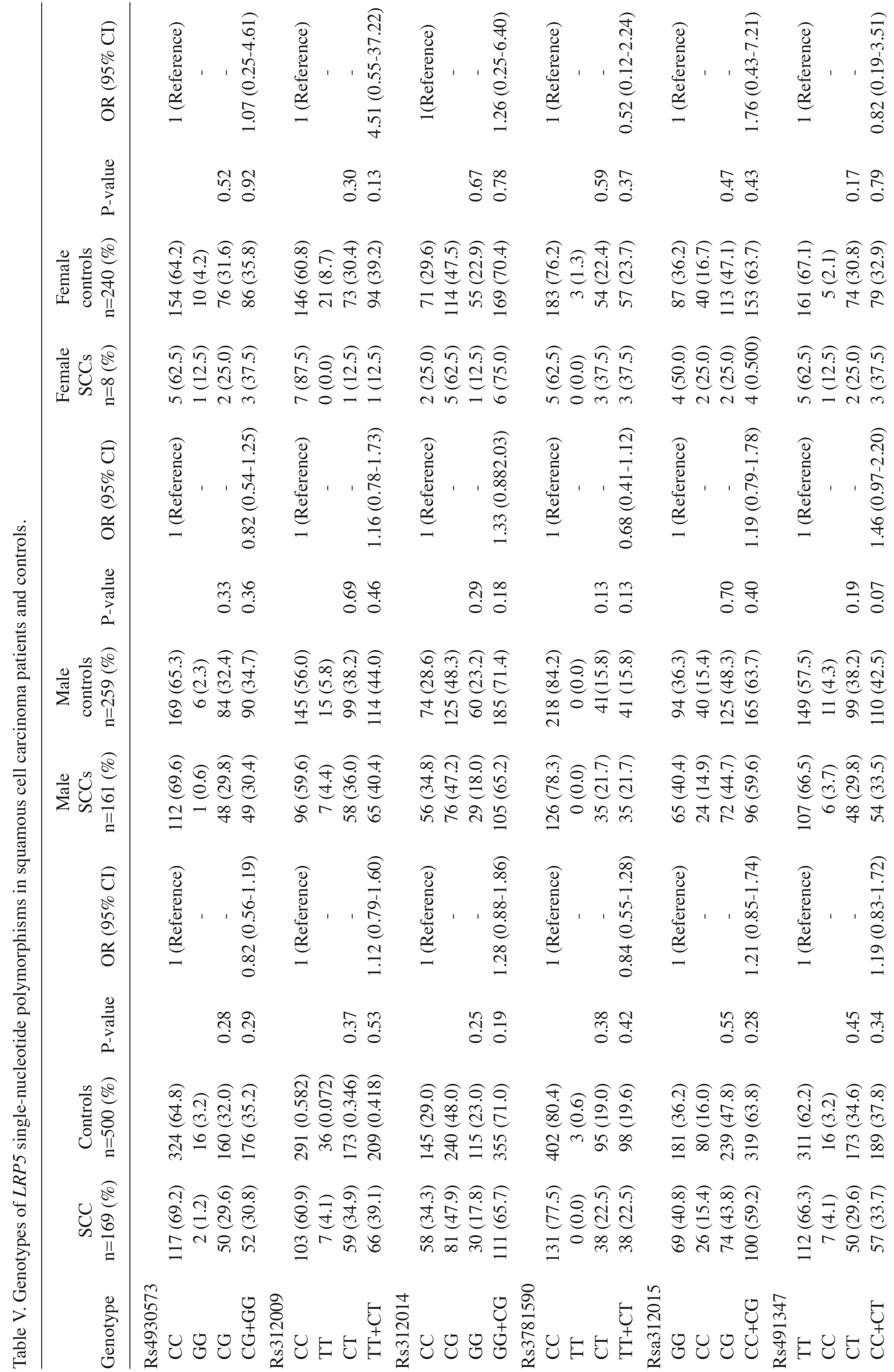




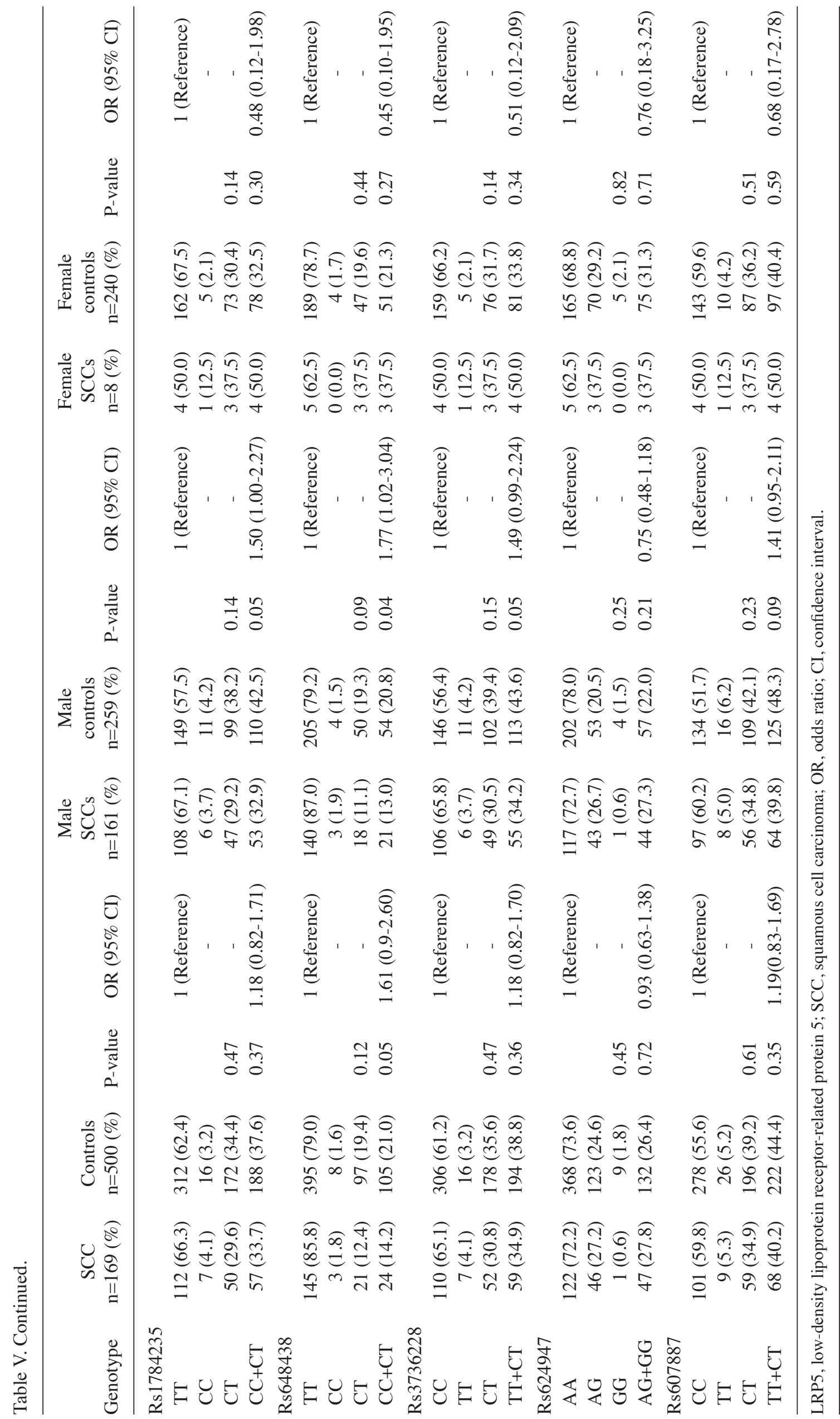


Table VI. Haplotype distribution and formation between patients and controls for association of haplotype blocks with non-small cell lung cancer risk.

\begin{tabular}{|c|c|c|c|c|c|c|}
\hline \multirow[b]{2}{*}{ Block } & \multirow[b]{2}{*}{ Loci } & \multirow[b]{2}{*}{ Cases/controls } & \multirow[b]{2}{*}{ Haplotype } & \multicolumn{2}{|c|}{ Frequency $(\%)$} & \multirow[b]{2}{*}{ P-value } \\
\hline & & & & Cases & Controls & \\
\hline \multirow[t]{18}{*}{ Block 1} & \multirow[t]{18}{*}{ rs312009 and 3120015} & NSCLC patients & CG & 60.2 & 60.0 & 0.93 \\
\hline & & Controls & $\mathrm{TC}$ & 24.4 & 24.5 & 0.98 \\
\hline & & & $\mathrm{CC}$ & 15.4 & 15.5 & 0.94 \\
\hline & & Male NSCLC patients & CG & 60.1 & 60.3 & 0.96 \\
\hline & & Male controls & $\mathrm{TC}$ & 25.1 & 24.8 & 0.89 \\
\hline & & & $\mathrm{CC}$ & 14.7 & 14.9 & 0.92 \\
\hline & & ADC patients & $\mathrm{CG}$ & 58.9 & 60.0 & 0.65 \\
\hline & & Controls & $\mathrm{TC}$ & 25.8 & 24.4 & 0.52 \\
\hline & & & $\mathrm{CC}$ & 15.3 & 15.5 & 0.88 \\
\hline & & Male ADC patients & $\mathrm{CG}$ & 57.9 & 60.2 & 0.49 \\
\hline & & Male controls & $\mathrm{TC}$ & 27.5 & 24.7 & 0.34 \\
\hline & & & $\mathrm{CC}$ & 14.6 & 14.9 & 0.89 \\
\hline & & Female NSCLC patients & $\mathrm{CG}$ & 60.3 & 59.8 & 0.88 \\
\hline & & Female controls & $\mathrm{TC}$ & 22.7 & 24.0 & 0.68 \\
\hline & & & $\mathrm{CC}$ & 17.0 & 16.2 & 0.78 \\
\hline & & Female ADC patients & $\mathrm{CG}$ & 60.2 & 59.8 & 0.91 \\
\hline & & Female controls & $\mathrm{TC}$ & 23.6 & 24.0 & 0.91 \\
\hline & & & $\mathrm{CC}$ & 16.2 & 16.2 & 0.98 \\
\hline \multirow[t]{18}{*}{ Block 2} & \multirow{18}{*}{$\begin{array}{l}\text { rs491347, rs } 1784235 \\
\text { and rs607887 }\end{array}$} & NSCLC patients & TTC & 76.6 & 74.6 & 0.28 \\
\hline & & Controls & $\mathrm{CCT}$ & 18.3 & 19.9 & 0.37 \\
\hline & & & TTT & 4.3 & 4.9 & 0.53 \\
\hline & & Male NSCLC patients & TTC & 76.1 & 72.2 & 0.12 \\
\hline & & Male controls & CCT & 18.8 & 22.8 & 0.09 \\
\hline & & & TTT & 4.0 & 4.5 & 0.70 \\
\hline & & ADC patients & TTC & 76.6 & 74.6 & 0.36 \\
\hline & & Controls & CCT & 18.3 & 19.9 & 0.41 \\
\hline & & & TTT & 4.4 & 4.9 & 0.62 \\
\hline & & Male ADC patients & TTC & 75.6 & 72.2 & 0.25 \\
\hline & & Male controls & $\mathrm{CCT}$ & 19.5 & 22.7 & 0.25 \\
\hline & & & TTT & 3.5 & 4.5 & 0.46 \\
\hline & & SCC patients & TTC & 76.8 & 74.6 & 0.42 \\
\hline & & Controls & CCT & 18.4 & 19.9 & 0.56 \\
\hline & & & TTT & 4.2 & 4.9 & 0.58 \\
\hline & & Male SCC patients & TTC & 77.0 & 72.2 & 0.12 \\
\hline & & Male controls & CCT & 18.0 & 22.8 & 0.10 \\
\hline & & & TTT & 4.4 & 4.5 & 0.95 \\
\hline \multirow[t]{12}{*}{ Block 3} & \multirow{12}{*}{$\begin{array}{l}\text { rs } 491347, \text { rs } 1784235 \\
\text { rs607887 and } \\
\text { rs3736228 }\end{array}$} & Female NSCLC patients & TTCC & 77.6 & 77.1 & 0.85 \\
\hline & & Female controls & CCTT & 16.3 & 16.7 & 0.90 \\
\hline & & & TTTC & 4.0 & 4.2 & 0.92 \\
\hline & & & TTTT & 1.0 & 1.3 & 0.75 \\
\hline & & Female ADC patients & TTCC & 78.1 & 77.1 & 0.73 \\
\hline & & Female controls & CCTT & 15.8 & 16.7 & 0.77 \\
\hline & & & TTTC & 4.3 & 4.2 & 0.96 \\
\hline & & & TTTT & 1.1 & 1.3 & 0.81 \\
\hline & & Female SCC patients & TTCC & 68.7 & 77.1 & 0.43 \\
\hline & & Female controls & CCTT & 25.0 & 16.7 & 0.38 \\
\hline & & & TTTC & 0.0 & 4.2 & 0.40 \\
\hline & & & TTTT & 0.0 & 1.3 & 0.65 \\
\hline \multirow[t]{2}{*}{ Block 4} & rs312009, rs3120014 & SCC patients & CGC & 57.6 & 52.4 & 0.09 \\
\hline & and rs3120015 & Controls & $\mathrm{TCG}$ & 21.6 & 24.4 & 0.29 \\
\hline
\end{tabular}


Table VI. Continued.

\begin{tabular}{|c|c|c|c|c|c|c|}
\hline \multirow[b]{2}{*}{ Block } & \multirow[b]{2}{*}{ loci } & \multirow[b]{2}{*}{ Cases/controls } & \multirow[b]{2}{*}{ Haplotype } & \multicolumn{2}{|c|}{ Frequency $(\%)$} & \multirow[b]{2}{*}{ P-value } \\
\hline & & & & Case & Control & \\
\hline & & & $\mathrm{CCG}$ & 15.0 & 14.9 & 0.94 \\
\hline & & & CGG & 5.1 & 7.7 & 0.11 \\
\hline & & Male SCC patients & CGC & 58.0 & 52.3 & 0.10 \\
\hline & & Male controls & TCG & 22.3 & 24.7 & 0.44 \\
\hline & & & $\mathrm{CCG}$ & 14.6 & 24.5 & 0.97 \\
\hline & & & CGG & 4.7 & 7.9 & 0.07 \\
\hline & & Female SCC patients & CGC & 49.9 & 52.4 & 0.84 \\
\hline & & Female controls & TCG & 6.2 & 24.0 & 0.10 \\
\hline & & & $\mathrm{CCG}$ & 24.9 & 15.3 & 0.30 \\
\hline & & & CGG & 12.6 & 7.4 & 0.45 \\
\hline & & & $\mathrm{CCC}$ & 6.4 & 0.9 & 0.04 \\
\hline
\end{tabular}

NSCLC, non-small cell lung cancer; ADC, adenocarcinoma; SCC, squamous cell carcinoma.

\section{Discussion}

In the current study, we investigated the association between LRP5 polymorphisms and NSCLC risk. We observed that LRP5 rs3736228 and rs648438 polymorphisms were strongly associated with the risk of NSCLC and lung SCC. Based on this finding, rs3736228 and rs648438 are two novel susceptibility loci that were associated with an increased risk of developing NSCLC in this Chinese male population. To the best of our knowledge, this is the first study describing the association of rs3736228 and rs648438 SNPs with NSCLC risk in humans.

LRP5 is a co-receptor for canonical Wnt-mediated signaling (8). In transgenic mice, loss of LRP5 expression markedly reduces the formation of mammary tumors (19). In osteosarcoma tissue, the expression of LRP5 mRNA has been correlated with metastatic disease and a poorer event-free survival in patients (20). Moreover, dominant-negative LRP5 inhibits the growth and metastasis of osteosarcoma in animal models and reduces the expression of cancer cell invasion-associated markers (including N-cadherin, Snail and matrix metalloprotease-2) (21). Thus, these data suggest that LRP5 may function as an oncogene. In the current study, we analyzed rs3736228 and rs648438 SNPs, which are localized in the region of the LRP5 gene on 11q13.2. A previous study has revealed that chromosome $11 \mathrm{q}$ is a susceptibility region for NSCLC (17). The present study confirmed these data, suggesting that LRP5 may be a candidate susceptibility gene for NSCLC.

By selecting the Tag SNPs across the LRP5 gene from the HapMap CHB database using the approach of Carlson et al (22), the criteria for the selection of Tag SNPs enabled us to maximize the power to detect SNPs (the statistical power of our study was $>80 \%$ ); thus, 11 SNPs were selected and two SNPs (rs3736228 and rs648438) were associated with NSCLC risk, which indicated that this methodology is useful in identifying susceptibility loci for NSCLC.

Furthermore, rs 3736228 is a SNP in LRP5, which is also known as Ala1330Val or A1330V; the more common C allele encodes Ala, while the rarer $\mathrm{T}$ allele encodes Val, and the latter is the risk allele. In the LRP5 gene, a $\mathrm{C} \rightarrow \mathrm{T}$ transition at rs3736228 results in a substitution of Val for Ala, and this transition significantly decreases the response to canonical Wnt signaling (23). Published data have identified that polymorphisms of rs3736228 are associated with a decrease in bone mineral density in postmenopausal Maya-mestizo females (24), Mexican females (25), healthy fertile French females (26), Japanese male workers (27), Chinese patients (28), and Chinese patients with osteoporosis $(29,30)$. However, to date, there are no studies describing an association between rs3736228 polymorphisms and lung cancer. In the present study, we noted that individuals with the rs3736228 $\mathrm{C}$ allele had a lower risk of developing NSCLC compared with those carrying the T allele. Compared with the $\mathrm{C} / \mathrm{C}$ homozygote, other genotypes $(\mathrm{C} / \mathrm{T}$ and $\mathrm{T} / \mathrm{T}$ ) had a greater risk of developing NSCLC in the male population, but not in the female population. The reason for this discrepancy is not clear, but it may be due to the fact that a high percentage of males in China smoke cigarettes (over 90\% of the males in our study were smokers, compared with less than $10 \%$ of the females). Polymorphisms of rs3736228 have a combined effect with cigarette smoking; people that smoke cigarettes (current and former smokers) with rs3736228 polymorphisms have a 4.1-fold greater $(95 \% \mathrm{CI}, 1.6-10.2)$ risk of having metabolic syndrome (31). In addition, tobacco smokers have a much greater chance of developing lung cancer (32). Our results suggest that, among smokers, East Asian males with the rs3736228 SNP have a higher susceptibility to develop NSCLC.

Another potential susceptibility locus for NSLCL risk was determined to be rs648438 in our current study. Rs648438 is located in the intron region of LRP5, which has not been reported to be associated with any diseases. The present study reveals that an rs648438 polymorphism was associated with lung SCC development in males carrying at least one $\mathrm{C}$ allele $(\mathrm{C} / \mathrm{C}$ and $\mathrm{C} / \mathrm{T})$ compared with those carrying the T/T homozygote. In this study, there were 549 male smokers among the 609 male subjects (including cases and controls), whereas there were only 35 female smokers among the 490 female 
subjects. Tobacco smoking is a strong risk factor for all types of lung cancer, and among male smokers SCC is the predominant subtype: the greater the amount smoked, the greater the proportion of SCC cases relative to ADC cases (18). The current data indicated that among smokers, East Asian males with rs648438 had a higher susceptibility of developing SCC.

Although these two potential susceptibility loci are novel and were associated with an increased risk of NSCLC, the present study does have certain limitations, For example, our eligible population was living in Zhejiang province, China. Gene polymorphisms are known to be influenced by ethnicity, location and environment. Therefore, further investigation is required to confirm our data using other ethnicities.

\section{Acknowledgements}

The authors thank Xiaohong $\mathrm{Xu}$ and Yejiang Bao for their assistance in control screening. They also thank Hailong Liu for his technical support. The abstract of this paper was previously published at the 6th Asian Oncology Summit and 10th Annual Conference of the Organisation for Oncology and Translational Research, 11 April 2014-13 April 2014: www.ejcancer.com/article/S0959-8049(14)00306-2/abstract.

\section{References}

1. Jemal A, Bray F, Center MM, Ferlay J, Ward E and Forman D: Global cancer statistics. CA Cancer J Clin 61: 69-90, 2011.

2. Molina JR, Yang P, Cassivi SD, Schild SE and Adjei AA: Non-small cell lung cancer: epidemiology, risk factors, treatment, and survivorship. Mayo Clin Proc 83: 584-594, 2008.

3. Schwartz AG, Wenzlaff AS, Bock CH, Ruterbusch JJ, Chen W, Cote ML, Artis AS, Van Dyke AL, Land SJ, Harris CC, et al: Admixture mapping of lung cancer in 1812 African-Americans. Carcinogenesis 32: 312-317, 2011.

4. Alberg AJ and Samet JM: Epidemiology of lung cancer. In: Murray \& Nadel's Textbook of Respiratory Medicine. Mason RJ et al (eds). 5th edition. Saunders Elsevier, Amsterdam, pp. 927-939, 2010.

5. Matakidou A, Eisen T and Houlston RS: Systematic review of the relationship between family history and lung cancer risk. Br J Cancer 93: 825-833, 2005.

6. Hung RJ, McKay JD, Gaborieau V, Boffetta P, Hashibe M, Zaridze D, Mukeria A, Szeszenia-Dabrowska N, Lissowska J, Rudnai $\mathrm{P}$, et al: A susceptibility locus for lung cancer maps to nicotinic acetylcholine receptor subunit genes on $15 \mathrm{q} 25$. Nature 452: 633-637, 2008

7. Zhang Y, Hua S, Zhang A, Kong X, Jiang C, Deng D and Wenlong B: Association between polymorphisms in COMT, PLCH1, and CYP17A1, and non-small-cell lung cancer risk in Chinese nonsmokers. Clin Lung Cancer 14: 45-49, 2013.

8. Tamai K, Semenov M, Kato Y, Spokony R, Liu C, Katsuyama Y, Hess F, Saint-Jeannet JP and He X: LDL-receptor-related proteins in Wnt signal transduction. Nature 407: 530-535, 2000.

9. Dieckmann M, Dietrich MF and Herz J: Lipoprotein receptors - an evolutionarily ancient multifunctional receptor family. Biol Chem 391: 1341-1363, 2010.

10. Joiner DM, Ke J, Zhong Z, Xu HE and Williams BO: LRP5 and LRP6 in development and disease. Trends Endocrinol Metab 24: 31-39, 2013.

11. MacDonald BT, Tamai K and He X: Wnt/beta-catenin signaling: components, mechanisms, and diseases. Dev Cell 17: 9-26, 2009

12. Lee EH, Chari R, Lam A, Ng RT, Yee J, English J, Evans KG, Macaulay C, Lam S and Lam WL: Disruption of the non-canonical WNT pathway in lung squamous cell carcinoma. Clin Med Oncol 2008: 169-179 2008.

13. Clevers H: Wnt/beta-catenin signaling in development and disease. Cell 127: 469-480, 2006.

14. Staal FJ and Clevers HC: WNT signalling and haematopoiesis: a WNT-WNT situation. Nat Rev Immunol 5: 21-30, 2005.
15. El Wakil A and Lalli E: The Wnt/beta-catenin pathway in adrenocortical development and cancer. Mol Cell Endocrinol 332: 32-37, 2011.

16. Liu CX, Musco S, Lisitsina NM, Forgacs E, Minna JD and Lisitsyn NA: LRP-DIT, a putative endocytic receptor gene, is frequently inactivated in non-small cell lung cancer cell lines. Cancer Res 60: 1961-1967, 2000.

17. Berrieman HK, Ashman JN, Cowen ME, Greenman J, Lind MJ and Cawkwell L: Chromosomal analysis of non-small-cell lung cancer by multicolour fluorescent in situ hybridisation. Br J Cancer 90: 900-905, 2004

18. Pesch B, Kendzia B, Gustavsson P, Jöckel KH, Johnen G, Pohlabeln H, Olsson A, Ahrens W, Gross IM, Brüske I, et al: Cigarette smoking and lung cancer-relative risk estimates for the major histological types from a pooled analysis of case-control studies. Int J Cancer 131: 1210-1219, 2012.

19. Lindvall C, Evans NC, Zylstra CR, Li Y, Alexander CM and Williams BO: The Wnt signaling receptor Lrp5 is required for mammary ductal stem cell activity and Wnt1-induced tumorigenesis. J Biol Chem 281: 35081-35087, 2006.

20. Hoang BH, Kubo T, Healey JH, Sowers R, Mazza B, Yang R, Huvos AG, Meyers PA and Gorlick R: Expression of LDL receptor-related protein 5 (LRP5) as a novel marker for disease progression in high-grade osteosarcoma. Int J Cancer 109: 106-111, 2004.

21. Guo Y, Rubin EM, Xie J, Zi X and Hoang BH: Dominant negative LRP5 decreases tumorigenicity and metastasis of osteosarcoma in an animal model. Clin Orthop Relat Res 466: 2039-2045, 2008.

22. Carlson CS, Eberle MA, Rieder MJ, Yi Q, Kruglyak L and Nickerson DA: Selecting a maximally informative set of single-nucleotide polymorphisms for association analyses using linkage disequilibrium. Am J Hum Genet 74: 106-120, 2004

23. Kiel DP, Ferrari SL, Cupples LA, Karasik D, Manen D, Imamovic A, Herbert AG and Dupuis J: Genetic variation at the low-density lipoprotein receptor-related protein 5 (LRP5) locus modulates Wnt signaling and the relationship of physical activity with bone mineral density in men. Bone 40: 587-596, 2007.

24. Canto-Cetina T, Polanco Reyes L, González Herrera L, Rojano-Mejía D, Coral-Vázquez RM, Coronel A and Canto P: Polymorphism of LRP5, but not of TNFRSF11B, is associated with a decrease in bone mineral density in postmenopausal maya-mestizo women. Am J Hum Biol 25: 713-718, 2013.

25. Falcón-Ramírez E, Casas-Avila L, Cerda-Flores RM, Castro-Hernández C, Rubio-Lightbourn J, Velázquez-Cruz R, Diez-G P, Peñaloza-Espinosa R and Valdés-Flores M: Association of LRP5 haplotypes with osteoporosis in Mexican women. Mol Biol Rep 40: 2705-2710, 2013.

26. Massart F, Marini F, Bianchi G, Minisola S, Luisetto G, Pirazzoli A, Salvi S, Micheli D, Miccoli M, Baggiani A, et al: Genetic predictors of skeletal outcomes in healthy fertile women: the Bonturno study. Joint Bone Spine 80: 414-419, 2013.

27. Funakoshi Y, Omori H, Yada H and Katoh T: A1330V polymorphism of the low-density lipoprotein receptor-related protein 5 gene and bone mineral density in Japanese male workers. Environ Health Prev Med 16: 106-112, 2011

28. Jiang XY, Chen Y, Xu L, Li X, Cao FF, Li L, Lu M, Jin L and Wang XF: Association of LPR5 polymorphism with bone mass density and cholesterol level in population of Chinese Han. Exp Clin Endocrinol Diabetes 118: 388-391, 2010.

29. Zhang YP, Deng FY, Chen Y, Pei YF, Fang Y, Guo YF, Guo X, Liu XG, Zhou Q, Liu YJ and Deng HW: Replication study of candidate genes/loci associated with osteoporosis based on genome-wide screening. Osteoporos Int 21: 785-795, 2010.

30. Jiang XY, Chen HH, Cao FF, Li L, Lin RY, Wen H, Jin L and Wang XF: A polymorphism near osteoprotegerin gene confer risk of obesity in Uyghurs. Endocrine 37: 383-388, 2010.

31. Yang CW, Li CI, Liu CS, Bau DT, Lin CH, Lin WY, Li TC and Lin CC: The joint effect of cigarette smoking and polymorphisms on LRP5, LEPR, near MC4R and SH2B1 genes on metabolic syndrome susceptibility in Taiwan. Mol Biol Rep 40: 525-533, 2013.

32. Frusch N, Bosquée L and Louis R: Lung cancer. Epidemiology and etiologic factors. Rev Med Liege 62: 548-553, 2007 (In French). 